\title{
Effect of paper industry effluent on enzyme activity and protein profiling of Chickpea (Cicer arietinum L.)
}

\author{
${ }^{1}$ Rajat Chaudhary $^{1^{*}}$,Anurag Mishra ${ }^{2}$, Kapil Kumar $^{3}$ and Sonam Arya ${ }^{2}$ \\ ${ }^{1}$ Department of Biosciences, D.A.V. (P.G.) Collage, Muzaffarnagar-251001 (U.P.), INDIA \\ ${ }^{2}$ Department of Agriculture Biotechnology, Sardar Vallabhbhai Patel University of Agriculture and Technology, \\ Meerut-250110(U.P.), INDIA \\ ${ }^{3}$ Department of Entomology, Sam Higginbottom Institute of Agriculture, Technology and Sciences, Allahabad- \\ 211007 (U.P.), INDIA \\ *Corresponding author. E-mail: rajatbio007@gmail.com.
}

Received: November 8, 2016; Revised received: May 5, 2017; Accepted: September 7, 2017

\begin{abstract}
Chickpea (Cicer arietinum L.) is a legume which is mostly cultivated in India than other countries that can give significant amounts of dietary minerals and protein to humans. The effect of paper industrial effluent on chickpea (C. arietinum L.) were analysed along with different concentration (10\%, 20\% 40\%, 60\% $80 \%$ and $100 \%)$ and pure tap water as a control to compare the effect of paper industrial effluent for one week. The amount of protein were comparable with control, their amount was increased at $40 \%$ in effluent treated seeds. The maximum activity of enzymes was found below $40 \%$ level of effluent. In this study protein profile of imbibed seeds, shoot, root and residual cotyledons were examined under the different concentration of effluent. Polyacrylamide gel electrophoresis of total protein showed that the maximum number of protein bands seen in the imbibed seeds whereas minimum number of protein bands observed in the root. SDS-PAGE revealed that less degradation and/or more rapid accumulation of proteins occurred in higher molecular weight proteins. From this study, it is clear that the industrial effluent rich in organic matter and plant nutrients are finding their use in agriculture as the cheaper way of disposal.
\end{abstract}

Keywords: Amylase, Chickpea, Imbibed seeds, Paper industry effluent, SDS-PAGE

\section{INTRODUCTION}

Chickpea (C. arietinum L.) is a legume crop, which belongs to the family Fabaceae. It is the second most important legume crop after dry beans (Varshneyet al., 2012). It is a valuable source of protein, carbohydrate, fibre and many essential vitamins and minerals (Roy et al., 2010). The amount of carbohydrate, protein and reducing sugar were increased under stress condition (Chaudhary et al., 2016 ). India has the first rank in the world, contributing $68 \%$ of the global chickpea production, cultivated in 9.21 million ha, producing a total of 8.22 million tonnes with an average yield of 892.5 $\mathrm{kg} / \mathrm{ha} \mathrm{(FAOSTAT,} \mathrm{2013).}$

Industrialisation is an important sign for the development of any nation. Today it has become a matter of major concern in the deterioration of the environment; with the rapid growth of industries the industrial waste water has increased tremendously (Amathussalam et al., 2002). Agriculture is the backbone of any economy, nowadays it has been adversely affected by the upsurge in the indiscriminate dumping and disposal of the wastes into land and watercourses. If the excessive amount of these waste are absorbed by plants, the yield may get reduced and the plant may die due to phytotoxicity (Singh and Sakal, 2001). Water resources are affected by industrial pollution extremely. Pollution caused by industrial effluents is a severe problem throughout the world. Paper industrial effluent that has not been treated properly has an obnoxious odour when discharged into the environment. The effluents not only affect the plant growth but also degrade the soil properties when used for irrigation (Patel et al., 2004). So it is necessary to conduct experiments to find out the impact of these effluents on agricultural crops before they are recommended for irrigation. A laboratory experiment was designed to know the effect of different concentration $(0-100 \%)$ of paper industrial effluent on protein content, enzyme activity and profile of protein in chickpea using SDS-PAGE.

\section{MATERIALS AND METHODS}

Seed selection: Seed of uniform size, shape, colour and weight were selected. Now seed was sterilised with the $\mathrm{HgCl}_{2}$ solution, washed thoroughly with distilled water and kept in different concentration of industrial effluent separately. Seed simultaneously kept in distilled water, which constituted as a control. After requisite imbibitions of 42 hours, germination was assessed by radical emergence ( $2-3 \mathrm{~mm})$.

Effluent collection and experimental setup: The 
effluent sample was collected from paper industry in 5liter plastic cans and then stored in dark room and diluted in different concentration $(10,20,40,60,80$, and $100 \%$ ). Chickpea seeds were imbibed in different concentration of paper industrial effluent for up to 24 hours and were grown in Petri plates in three replications and irrigated by different concentration of effluent for up to 7 days for germination. Control was irrigated with an equal volume of distilled water. After 7 days, root shoot separated out from each other by cutting for the analysis. Five seedlings were collected from each treatment and were analysed.

\section{Enzyme activity analysis}

Assay of $\boldsymbol{\alpha}$-amylase: the $50 \mathrm{mg}$ sample was homogenised in $8 \mathrm{ml}$ buffer $(0.2 \mathrm{M}$ Tris-Malate Buffer, $\mathrm{pH}$ 7.2,) and centrifuged at $5000 \mathrm{rpm}$ for $5 \mathrm{~min}$. The supernatant was taken and make up the volume $8 \mathrm{ml}$ with the buffer. $1 \mathrm{ml}$ of enzyme extract and $1 \mathrm{ml}$ of the substrate (starch) were added in a test tube and keep at room temperature for $10 \mathrm{~min}$. Add $3 \mathrm{ml}$ of quenching reagent (Iodine) and take O.D. at 620nm (Filner and Varner, 1967).

Assay of $\boldsymbol{\beta}$-amylase: the $50 \mathrm{mg}$ sample was crushed in $0.05 \mathrm{~N}$ phosphate buffer, $\mathrm{pH} 7$, centrifuged at $5000 \mathrm{rpm}$ for $5 \mathrm{~min}$. The supernatant was taken and make up the volume $8 \mathrm{ml}$ with the buffer. $100 \mu 1$ sample, $2.9 \mathrm{ml}$ of phosphate buffer and $2 \mathrm{ml}$ of DNS reagent was added, incubated in boiling water bath for $5 \mathrm{~min}$. and take O.D. at 570nm (Bernfeld, 1995).

Assay of acid phosphate: the $1 \mathrm{gm}$ sample was homogenised in $8 \mathrm{ml}$ buffer (acetate buffer, $\mathrm{pH} \mathrm{5}$ ) and centrifuged at $5000 \mathrm{rpm}$ for $5 \mathrm{~min}$. $50 \mu \mathrm{l}$ supernatant and $25 \mu \mathrm{l}$ of PNpp was added and then make up the volume $8 \mathrm{ml}$ by $2.925 \mathrm{ml}$ of acetate buffer, and incubate at $300^{\circ} \mathrm{C}$ for $30 \mathrm{~min} .2 \mathrm{ml}$ of $\mathrm{NaOH}$ was added and take O.D. at 430nm (Lea, 1990; Prince et al., 1982; Wilson et al., 1996; Sawhney and Randhir, 2007)

Assay of alkaline phosphatase: the 1 gm sample was homogenised in $8 \mathrm{ml}$ buffer (1M Tris buffer, $\mathrm{pH} 7.5$ ) and centrifuged at $5000 \mathrm{rpm}$ for $5 \mathrm{~min}$. the $50 \mu \mathrm{l}$ supernatant and $25 \mu \mathrm{l}$ of PNpp were added and then make up the volume by $2.925 \mathrm{mlTris}$ buffer and incubate at $30^{\circ} \mathrm{C}$ for 30 min. $2 \mathrm{ml}$ of $\mathrm{NaOH}$ was added and take O.D. at 430nm (Lea, 1990; Prince et al., 1982; Wilson et al., 1996; Sawhney and Randhir, 2007).

Total protein extraction and SDS-PAGE: Total protein was extracted by Lowry et al., (1951). The $50 \mathrm{mg}$ fresh plant sample was crushed with $8 \mathrm{ml}$ phosphate buffer and centrifuged at $5000 \mathrm{rpm}$ for $5 \mathrm{~min}$. The $50 \mu \mathrm{l}$ supernatant was taken and add $2.45 \mathrm{ml}$ of $0.1 \mathrm{~N} \mathrm{NaOH}$ and $2 \mathrm{ml}$ of reagent $\mathrm{A}$, incubated at $37^{\circ} \mathrm{C}$ for $30 \mathrm{~min}$., add $5 \mathrm{ml}$ of reagent $\mathrm{B}$ and again incubated at $50^{\circ} \mathrm{C}$ for 5 min and then O.D. was taken at $750 \mathrm{~nm}$. A standard curve of BSA (Bovine Serum Albumin) was used for quantification of protein. $200 \mu$ l Dye (Bromophenol blue) was added to each microtube, then mixed well and incubated at room temperature for $15 \mathrm{~min}$. SDS-PAGE electrophoresis was performed by $12 \%$ acrylamide separating gel and 4\% acrylamide stacking gel with $0.5 \mathrm{~mm}$ spacers. The separating gel contained $6.68 \mathrm{ml}$ of distilled water, $5 \mathrm{ml}$ of $1.5 \mathrm{M}$ Tris- $\mathrm{HCl}, \mathrm{pH}$ $8.8,200 \mu \mathrm{l}$ of $10 \%(\mathrm{w} / \mathrm{v})$ sodium dodecyl sulphate (SDS), $8 \mathrm{ml}$ of $30 \%$ acrylamide (Acrylamide, Bisacrylamide ratio $29.2: 0.8), 10 \mu \mathrm{l}$ of TEMED and 100 $\mu \mathrm{l}$ of $10 \%(\mathrm{w} / \mathrm{v})$ ammonium persulphate. The stacking gel consisted of $1.2 \mathrm{ml}$ of distilled water, 0.5 mlof 0.5 M Tris-HCl, $\mathrm{pH} 6.8,20 \mu \mathrm{l}$ of $10 \%$ (w/v) SDS, $267 \mu \mathrm{l}$ of $30 \%$ acrylamide, $2 \mu \mathrm{l}$ of TEMED and $10 \mu \mathrm{l}$ of $10 \%$ $(\mathrm{w} / \mathrm{v})$ ammonium persulphate.

$10 \mu \mathrm{g}$ of protein was mixed in a microtube with $1 / 20$ volume of $\beta$ - mercaptoethanol in a final volume of 10 $\mu 1$. After incubation at $95^{\circ} \mathrm{C}$ for $5 \mathrm{~min}$ and a brief cooling on ice, $10 \mu \mathrm{l}$ was loaded per lane and electrophoresed at $50 \mathrm{~mA}$ for 3-4 hours with $1 \mathrm{X}$ SDS-PAGE running buffer $(100 \mathrm{mM}$ glycine, $25 \mathrm{mM}$ Tris and $0.1 \%(\mathrm{w} / \mathrm{v}) \mathrm{SDS})$. The gels were stained with Coomassie Brilliant Blue R-250 solution [40\% (v/v) methanol, 10\% (v/v) acetic acid and $0.25 \%(\mathrm{w} / \mathrm{v})$ Coomassie Brilliant Blue R-250] and rocked at room temperature for $30 \mathrm{~min}$. These gels were destained [in $40 \%$ (v/ v) methanol, $10 \%(\mathrm{v} / \mathrm{v})$ acetic acid and $3 \%(\mathrm{v} / \mathrm{v})$ glycerol] at room temperature. Gel image was taken.

\section{RESULTS AND DISSCUSION}

The $\alpha$-amylase is an important enzyme plays an important role in the development of different parts of the plant by breaking stored starch molecules into glucose molecules. In imbibed seeds (IS), $\alpha$-amylase was shown maximum activity at $40 \%$ concentration of effluent in comparison to control. In shoot and residual cotyledons (RC), the maximum $\alpha$-amylase activity was observed at $40 \%$ concentration of effluent, while in root no effect was found (Fig. 1).The similar results also reported byDivyapriyaet al., (2014). $\alpha$-amylase activity were diminished progressively with increasing concentration of effluent (Chugh and Sawhney, 1996; Sang et al., 1997). The present investigation showed that, complete inhibition of seed germination above $80 \%$ effluent concentrations was correlated with less water uptake which was insufficient for triggering $\alpha$ amylase enzyme in seeds. All these changes (physiological and biochemical) in the seeds was observed due to the cumulative effect of excess amount ofTDS, pH, BOD and COD in the effluent (Chaudhary et al., 2016 ). This observation has the conformity with the result obtained Kumariet al., (2014)who reported that the germination of Vigna radiata, Oryza sativa, Acaiaholosericca, and Leucaenaleucocephala was totally inhibited at $75 \%$ and $100 \%$ tannery effluent.The $\beta$-amylase activity decreased with increase the concentration of industrial effluent (Fig.2). In IS, $\beta$-amylase activity increased with increasing the concentration of effluent and maximum activity was observed at $80 \%$ 


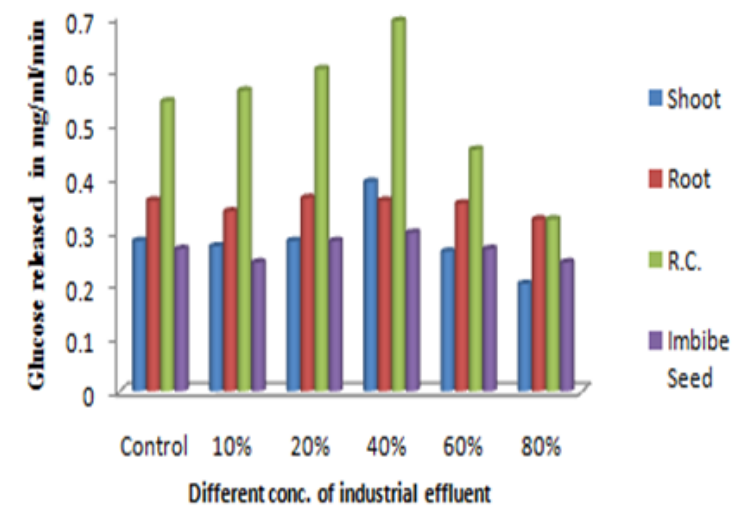

Fig. 1. Effect different concentration of industrial effluent on alpha amylase activity in germinating seeds after 7 days and imbibed of Cicer arietinum (cv. C-235).

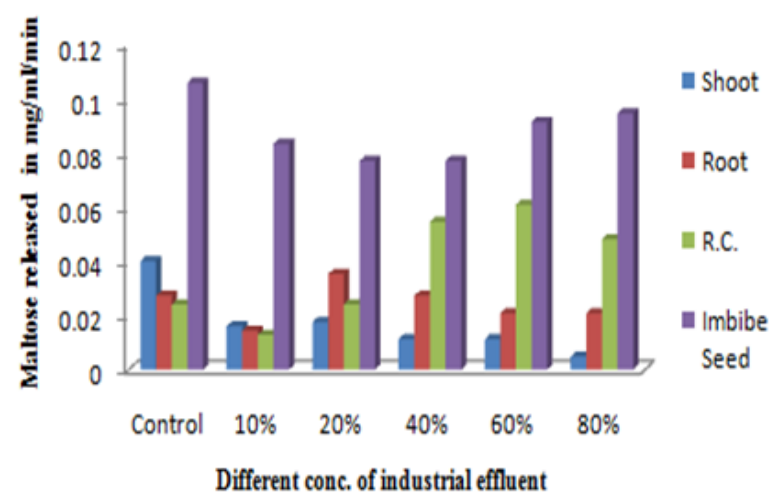

Fig. 2. Effect of different concentration of industrial effluent on Beta amylase activity in germinating seeds after 7 days and imbibed seeds of Cicer arietinum (cv. C-235).

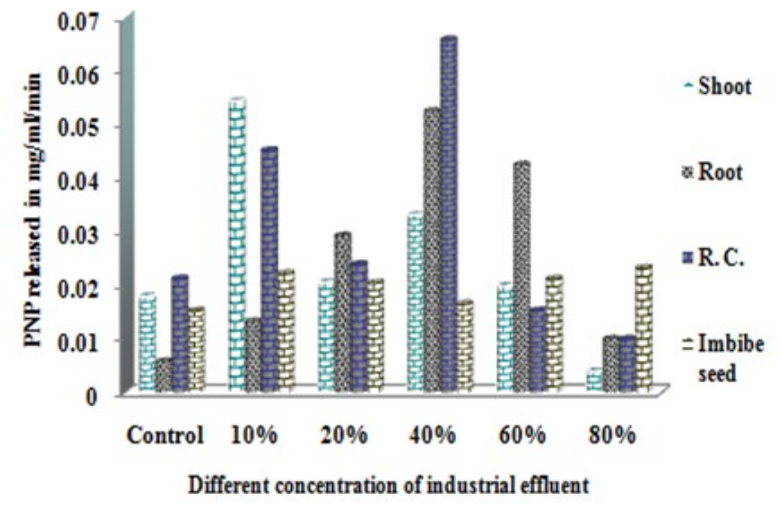

Fig. 3. Effect of the different concentration of industrial effluent on Acid phosphatase in imbibed seeds and seedling

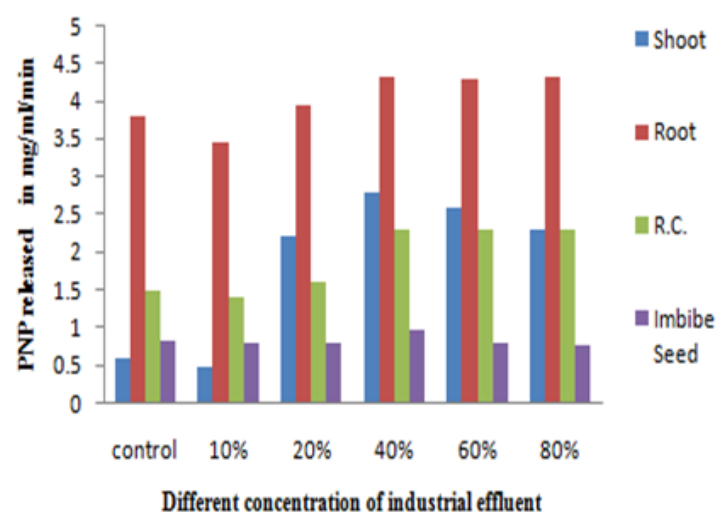

Fig. 4. Effect of different concentration of industrial effluent on Alkaline phosphatase in imbibed seeds and seedling parts of Cicer arietinum (cv. C-235).

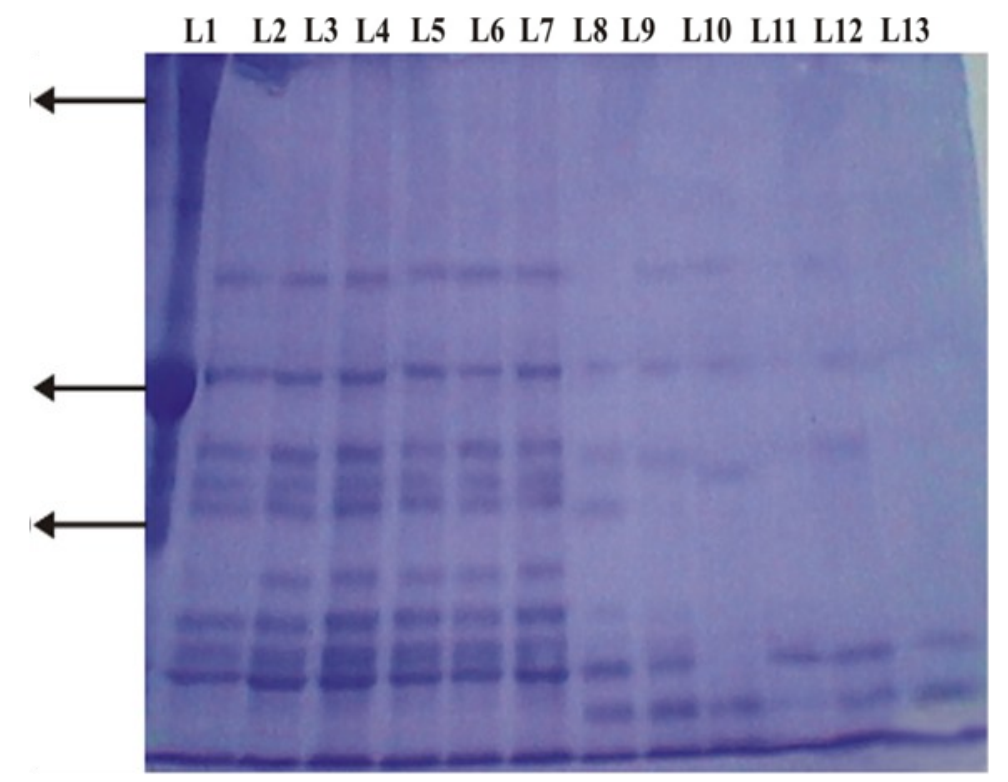

Fig. 5. Protein profile of Cicer arietinum imbibed seeds (IS) and residual cotyledon (RC) under control and treated (by paper industrial effluent) on 12\% SDS-PAGE [lane: 1- marker, lane: 2- control, lane: 3- IS (10\%),lane: 4- IS (20\%), lane: 5- IS (40\%),lane: 6- IS (60\%), lane: 7- IS (80\%), lane: 8- RC control, lane: 9- RC (10\%),lane: 10- RC (20\%), lane: 11- RC 


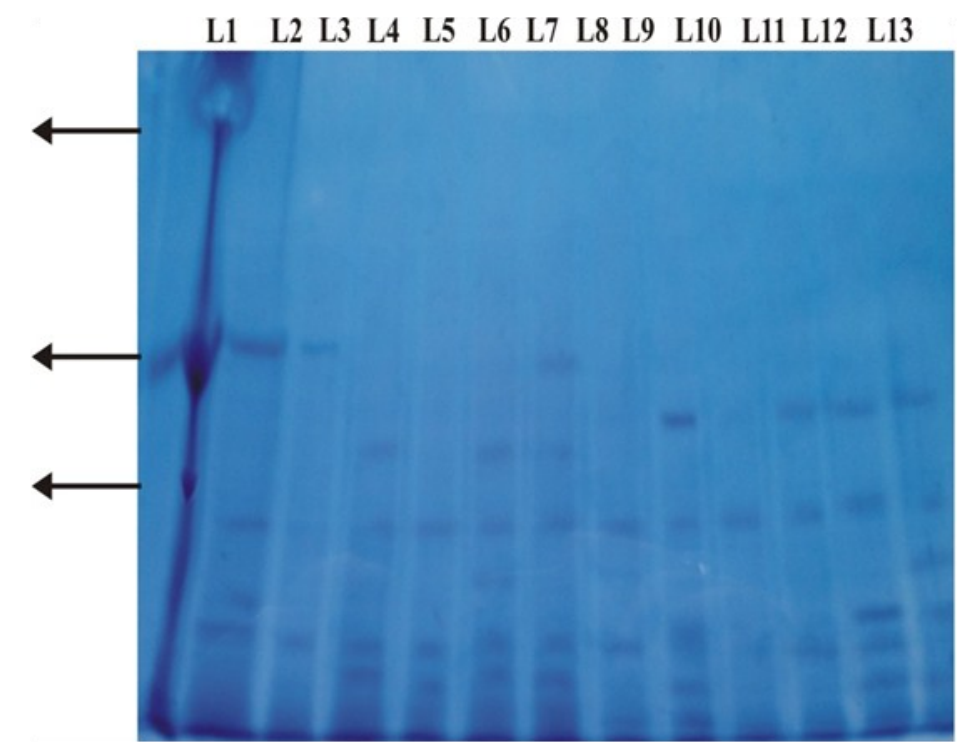

Fig. 6. Protein profile of Cicer arietinum root $(R)$ and shoot $(S)$ under control and treated (by paper industrial effluent) on $12 \%$ SDS-PAGE [lane: 1- marker, lane: 2- control, lane: 3- $R$ (10\%), lane: 4- $R$ (20\%),lane: 5- $R$ (40\%), lane: 6- $R$ (60\%), lane: 7- $R$ (80\%), lane: 8- S control, lane: 9- S (10\%), lane: 10- S (20\%), lane: 11-S (40\%), lane: 12-S (60\%), lane: 13- S (80\%)].

concentration but less than control. In shoot and root, the maximum activity of $\beta$-amylase was observed at $20 \%$ concentration of effluent but at other doses negligible effect was observed. While $\beta$-amylase activity was increased with increasing the concentration of effluent and maximum activity was observed at $60 \%$ concentration in $\mathrm{RC}$. The similar result also reported byUpadhyay and Pandey, (2013), as they investigated that the total amylase of wheat, maize and sweet pea was decreased under copper stress. The $\beta$-amylase activity was significantly decreased by increasing the concentration of effluent (Nath et al., 2005; Nath et al., 2009).

In IS, maximum activity was observed at $80 \%$ concentration and minimum at $40 \%$ concentration of effluent but that was less than control. While in the shoot, acid phosphatase activity was observed maximum at $10 \%$ concentration and minimum at $80 \%$ concentration of effluent in Fig. 3. But in roots and RC acid phosphatase activity was found maximum at $40 \%$ concentration and minimum at $80 \%$ concentration of effluent. Acid phosphatases have various metabolic functions but in adverse condition, enzyme activity was inhibited. So that plant in control condition had maximum activity (McLachlan, 1980; Duff et al., 1994). In IS no effect on enzyme activity was observed. In root, shoot and $\mathrm{RC}$, the alkaline phosphatase(optimum $\mathrm{pH}$ 8.0) activity was increased by increasing the concentration of effluent and maximum and minimum enzyme activity was found at $40 \%$ and $10 \%$ concentration of effluent respectively but less than control represented in Fig. 4. Alkaline phosphatase activity was decreased due to fluoride sensitivity at higher concentration of effluent (Kieleczawaet al., 1992). Acid phosphatase and alkaline phosphatase are phospho-hydrolytic en- zymes in supplying inorganic phosphate that is required for the maintenance of various cellular metabolisms such as the conversion of starch to sugar (McLachlan, 1980; Agoreyo, 2010). Maximum activity of enzymes was observedbelow $40 \%$ concentration of paper industrial effluent.

SDS-PAGE analysis: All the treatments of chickpea differ in the intensity of band as well as in a number of protein bands. The maximum number of bands was found in IS followed by RC, while root had less number of bands in comparison to shoot. In Fig. 5 three new proteins less than $45 \mathrm{KDa}$ were expressed in IS, while the intensity of bands increased with increasing the concentration of effluent as compared to control. A band of $60 \mathrm{KDa}$ proteins was present in control and treatments with different intensity and intensity of bands decreased in between 90-60 KDa with increasing the concentration of effluent.Two new bands were found less than $45 \mathrm{KDa}$ in $\mathrm{RC}$ and the intensity of bands maximum in control and bands intensity decreased as the concentration of effluent increased (Singh and Singh, 2015). Bands of molecular weight greater than $45 \mathrm{KDa}$ are present in control and absent in treatments. On the other hand, low-intensity bands less than $60 \mathrm{KDa}$ was expressed in control but as the concentration of effluent increased no band was observed.Seed storage protein profiles could be useful markers in the studies of genetic diversity (Hameed, et al., 2009 and Kakaei, et al., 2012).

Fig. 6 represents the comparative SDS-PAGE protein profiles of total proteins in chickpea under control and treatments. The highest variation in the electrophoretic profile of shoot and root protein was observed around 60 and $60-45 \mathrm{KDa}$ range proteins. Most of the protein was ranged from less than $60 \mathrm{KDa}$. In the shoot, bands 
of molecular weight greater than $45 \mathrm{KDa}$ are present in treatments and absent in control. New proteins were synthesised in stressed plants (Vitex and Chickpea) for their adaptation in the stressed conditions (John et al., 2011; Kaur et al., 2014 ) and maximum intensity of band was observed at $10 \%$ concentration and decreased with increasing the concentration of effluent (Singh and Singh, 2015). Bands of molecular weight less than $45 \mathrm{KDa}$ are present in treatments and absent in control. This suggests that the earlier expression of this category of proteins may have a role in tolerance response. Absence or presence of some bands may also indicate a functional involvement in stress response. The intensity of few bands remains the same in different concentrations of effluent because the protein content remains the same in all concentrations. Leaves storage protein profiles of $C$. arientinum could be useful markers in the studies of genetic diversity (Kakaei, et al., 2012 ). But in the root, bands of molecular weight $60 \mathrm{KDa}$ are slightly denser under control condition than treatments and intensity of band decreased with increasing the concentration of effluent. Some new protein bands were expressed less than and greater than $45 \mathrm{KDa}$, which indicate the functional involvement of the protein in stress condition.

\section{Conclusion}

The present study revealed that the paper industrial effluent at lower concentrations (10-40\%) promotes the growth and yield of $C$. arientinumbut the higher concentrations reduced the same though phytotoxic nature of effluent. Generally, tolerance in paper industrial effluent condition might be due to more rapid accumulation of proteins with higher molecular weight. Hence it was concluded that the number of new proteins was expressed in stressed plants for their adaptation in the stressed conditions. Such kind of proteins could be used as markers in identifying the stressed plants. This investigation is useful to identify the stressed plants. For further analysis using molecular markers will help to understand the genetic variations due to stress.

\section{ACKNOWLEDGEMENTS}

Authors are greatly thankful to Dr Manju Chauhan, HOD, D.A.V. (PG) College, Muzaffarnagar for providing necessary lab facilities to complete the work.

\section{REFERENCES}

Agoreyo, B.O. (2010). Acid phosphatase and alkaline phosphatase activities in ripening fruit of Musa Paradisiaca L. POJ., 3(3): 66-69.

Amthussalam, A., Abusbacker, M. N. and Jayabal, N. J. (2002). Growth and physiological activity of green gram under effluent stress. Ind. Poll. Con., 118-119.

Bernfeld, P. (1955). Amylase alpha and beta. Meth Enzymol., 1: $149-158$.

Chaudhary, R., Arya, S., Tyagi, S., Mishra, A. and Vaishali
(2016). Morphological and Biochemical Analysis of Cicer arietinum L. under Paper Industrial Effluent Stress conditions. Journal of Applied and Natural Science 8 (4): 2099-2103.

Chugh, L.K. and Sawhney, S.K. (1996). Effect of cadmium on germination, amylases and rate of respiration of germinating pea seeds. Environmental pollution, 92(1): $1-5$.

Divyapriya, S., Dimi, D. and Deepthi, K. P. (2014). Biochemical effect of industrial effluence on germinating seeds of Cicerarientum. International Journal of Pharmacy and Pharmaceutical Sciences, 6(2): 538-542.

Duff, S.M.G., Sarath, G. and Plaxton, W.T. (1994). The role of acid phosphatases in plant phosphorus metabolism. PhysiologiaPlantarum, 90(4): 791-800.

FAOSTAT (2013). Food and agriculture organization of the united nations at: http://faostat3.fao.org/home/ index.html.

Filner and Verner, J.E. (1967). A test for denovo synthesis of enzymes. Density labeling with $\mathrm{H}_{2} \mathrm{O}_{18}$ of barley, alpha amylase induced by gibberelic acid. Prac. Not $1 \mathrm{Acad}$, Sci., 58: 1520-1526.

Hameed, A., Shah, T.M., Atta, B.M., Iqbal, N., Haq M.A. and Ali, H. (2009). Comparative seed storage protein profiling of kabuli chickpea genotypes. Pak. J. Bot., 41 (2): 703-710.

John, D.B.A., Kumar, P.B.J.R., Gracelin, D.H.S.G. and Jency, S.S. (2011). Drought Stress and Its Impact on Protein in Three Species of Vitex. Journal of Stress Physiology \& Biochemistry, 7(3): 152-158.

Kakaei, M., Farshadfar, M., Moradi, F. and Mahmoudi, R. (2012). Study of Leaves and Seed Protein profiles of Chickpea (Cicerarientinum L.) under Drought Stress and non Stress conditions. Intl J Agri Crop Sci., 4 (6), 280-283.

Kaur, P., Kaur, J., Satvir Kaur, S., Singh, S. and Inderjit Singh, I. (2014). Salinity induced physiological and biochemical changes in chickpea (Cicer arietinum L.) genotypes.Journal of Applied and Natural Science 6 (2): 578-588.

Kieleczawa, J. Coughlan, S.J. and Hind, G. (1992). Isolation and Characterization of an Alkaline Phosphatase from Pea Thylakoids. Plant Physiol., 99(3): 1029-1036.

Kumar, S., Sahay, S.S. and Sinha, M.K. (1995). Bioassay of distillery effluent on common guppy, Lebister reticulates (peter) Bull. Environ. Contam. toxicol., 54: 309316.

Kumari,V., Kumar, S., Haq,I., Yadav, A., Singh, V.K., Ali, Z.and Raj, A. (2014). Effect of tannery effluent toxicity on seed germination amylase activity and early seedling growth of mung bean (vigna radiata) seeds. International Journal of Latest Research in Science and Technology, 3(4):165-170.

Lea, P.J. (1990). Methods in Plant Biochemistry. Vol 3. Enzyme of primary metabolism academic Press. New York.

McLachlan, K.D. (1980). Acid phosphatase activity of intact roots and phosphorus nutrition in plants. Australian Journal of Agricultural Research, 31(3): 429-440.

Nath, K., Saini, S. and Sharma, Y.K. (2005). Chromium in tannery industry effluent and its effect on plant metabolism and growth. Journal of Environmental Biology, 26(2): 197-204. 
Nath, K., Singh, D., Shyam, S. and Shama, Y.K. (2009). Phytotoxic effects of chromium and tannery effluent on growth and metabolism of Phaseolus mungoRoxb. Journal of Environmental Biology, 30(2): 227-34.

Prince, N.C. and Stevens, L. (1982). Fundamental of enzymology. Oxford university press. Oxford.

Patel, K.P., Pandya, R.R., Maliwal, G.L., Patel, K.C., Ramani, V.P. and George, V. (2004). Heavy metal content of different effluents and their relative availability in soil irrigated with effluent waters around major industrial cities of Gujarat. Journal of Indian Society of Soil Science. Vol. 52: 89-94.

Roy, F., Boye, J. and Simpson, B. (2010). Bioactive proteins and peptides in pulse crops: Pea, chickpea and lentil. Food Research International, 43: 432-442.

Sang Wan S, Babbers and Varghese, T.M. (1997). Effect of salinity on growth and soluble content J. Indian soc. Soil science, 3(9): 402-404.

Sawhney, S.K. and Singh, Randhir (2007). Introductory prat-
icalbiochemistry,Narosa Publishing House, 135- 142. New Delhi, INDIA.

Singh, A.P. and Sakal, R. (2001). Sewage sludge treated soils Distribution and translocation of micronutrient cations in different plant species. Sustainable use of Chemicals in Agriculture, 2: 23-32.

Singh, P.K. and Singh, D. (2015). Effect of $\gamma$ Radiation on Seed storage Proteins of Chickpea using SDS-PAGE. Sch. Acad. J. Biosci., 3(1B): 104-107.

Upadhyay, V.K. and Pandey, G.C. (2013). Studies on the physiological and biochemical parameters of Wheat, Maize and Sweet pea under copper stress. International Journal of Advanced Research. 1(4): 46-51.

Varshney, R. K., Ribaut, J. M., Buckler, E. S., Tuberosa, R., Rafalski, J. A. and Langridge, P. (2012). Can genomics boost productivity of orphan crops.Nat. Biotechnol, 30: 1172-1176.

Wilson, K. and walker, J. (1996). Practical biochemistry principles and techniques. Yedu Cambridge University Press. London. 